Article

\title{
Environmental and Economic Optimization of a Conventional Concrete Building Foundation: Selecting the Best of 28 Alternatives by Applying the Pareto Front
}

\author{
Ester Pujadas-Gispert ${ }^{1, *}$, Joost G. Vogtländer ${ }^{2}$ and S. P. G. (Faas) Moonen ${ }^{1}$ \\ 1 Department of the Built Environment, Eindhoven University of Technology, \\ 5600 MB Eindhoven, The Netherlands; S.P.G.Moonen@tue.nl \\ 2 Department of Industrial Design Engineering, Delft University of \\ Technology, 2628 CE Delft, The Netherlands; J.G.Vogtlander@tudelft.nl \\ * Correspondence: e.pujadas.gispert@tue.nl; Tel.: +31-40-247-6047
}

Citation: Pujadas-Gispert, E.; Vogtländer, J.G.; Moonen, S.P.G.(. Environmental and Economic Optimization of a Conventional Concrete Building Foundation: Selecting the Best of 28 Alternatives by Applying the Pareto Front. Sustainability 2021, 13, 1496. https:// doi.org/10.3390/su13031496

Academic Editor: Sunkuk Kim

Received: 12 December 2020

Accepted: 20 January 2021

Published: 1 February 2021

Publisher's Note: MDPI stays neutral with regard to jurisdictional claims in published maps and institutional affiliations.

Copyright: (c) 2021 by the authors. Licensee MDPI, Basel, Switzerland. This article is an open access article distributed under the terms and conditions of the Creative Commons Attribution (CC BY) license (https:// creativecommons.org/licenses/by/ $4.0 /)$.

\begin{abstract}
This research optimizes the environmental impact of a conventional building foundation in Northern Europe while considering the economic cost. The foundation is composed of piles and ground beams. Calculations are performed following relevant building Eurocodes and using life cycle assessment methodology. Concrete and steel accounted for the majority of the environmental impact of foundation alternatives; in particular, steel on piles has a significant influence. Selecting small sections of precast piles or low-reinforcement vibro-piles instead of continuous-flight auger piles can reduce the environmental impacts and economic costs of a foundation by $55 \%$ and $40 \%$, respectively. However, using precast beams rather than building them on site can increase the global warming potential (GWP) by up to $10 \%$. Increasing the concrete strength in vibro-piles can reduce the eco-costs, ReCiPe indicator, and cumulated energy demand (CED) by up to $30 \%$; the GWP by $25 \%$; and the economic costs by up to $15 \%$. Designing three piles instead of four piles per beam reduces the eco-costs and ReCiPe by $20-30 \%$, the GWP by $15-20 \%$, the CED by $15-25 \%$, and the costs by $12 \%$. A Pareto analysis was used to select the best foundation alternatives in terms of the combination of costs and eco-burdens, which are those with vibro-piles with higher concrete strengths (low reinforcement), cast in situ or prefabricated beams and four piles per beam.
\end{abstract}

Keywords: ground beam; LCA; prefabrication; vibro-pile; eurocode; precast prestressed concrete pile; continuous flight auger pile; eco-costs; life cycle assessment; economic

\section{Introduction \\ 1.1. Background}

To keep the global temperature rise preferably at no more than 1.5 degrees Celsius by the end of the century [1], it is necessary to diminish global emissions by more than $50 \%$ by 2030 and work towards carbon neutrality by 2050 . The construction sector accounts for $36 \%$ of final energy use and $39 \%$ of carbon dioxide $\left(\mathrm{CO}_{2}\right)$ related to energy and processes [2]. To date, the focus has been on reducing the energy consumed during the use of buildings. However, embodied energy related to the materials, construction, maintenance, and end of life of buildings is becoming increasingly important [3]. Life Cycle Assessment (LCA) has proven to be a suitable tool to reduce the environmental impact of buildings $[4,5]$. Nevertheless, uncertainties in the LCA calculation must be minimized and reliable benchmarks must be provided for evaluating buildings [6,7]. The LCA can be carried out at various levels of the system, such as for portions, components, or the entire building [8]. Nonetheless, the foundation, which is the lowest part of the building and in contact with the soil, is rarely assessed despite its considerable impact at an aggregate level, leaving ample room for improvement $[9,10]$. Consequently, rigorous studies are required to optimize foundations, thus reducing the emissions from the construction sector. 


\subsection{Deep Foundations}

A deep foundation is a type of foundation that depends on the deeper layers of the soil, while a shallow foundation is based on the surface layers of the soil [11]. Deep foundations tend to have a greater environmental impact than shallow foundations due to the greater amount of materials used [12,13]. A typical deep foundation for buildings and other civil works consists of piles, which are vertical structural elements driven or drilled deep into the ground at a building site. Piles tend to work in groups braced by ground beams, pile caps, and slabs. A conventional foundation in Northern Europe is composed of piles and ground beams. The foundation can be either built directly on the ground (cast in situ) or built in a factory (prefabricated) and then transported and installed on site [14]. During the installation, the joints between precast components are connected with steel reinforcing bars and sealed with mortar. Cast in situ beams can be built into different types of formwork (e.g., removable or non-removable, different materials and forms, etc.), and a blinding or plastic foil is often required at the bottom. Below are some of the most commonly used types of piles in Northern Europe [11]:

- $\quad$ Precast prestressed concrete (PPC) piles are prefabricated piles that are prestressed and driven in the ground using a diesel or hydraulic hammer (Figure 1). The main advantage of PPC piles over conventional precast piles is that they are more resistant given the same pile cross-section. Therefore, PPC piles are slender and lighter, making them easier to lift and drive. Additionally, the effect of prestressing closes the cracks of concrete caused during handling and driving, which combined with high-quality concrete, extends the durability of the prestressed pile.

- Fundex piles are built by drilling a metallic tube with a tip on the ground (Figure 2). Then, the reinforcement cage is installed and concrete is poured inside the tube. Finally, the metal tube is removed, leaving the sacrificial drill point in the soil, and the pile head is cut to ensure a good connection with the upper structure.

- Continuous flight auger (CFA) piles are drilled and concreted in one continuous operation, reducing installation time compared to bored piles (Figure 3). The reinforcement cage is then placed in the upper meters of the pile when concrete is still wet.

- Vibro-piles are built by driving a metal tube closed at the end by a sacrificial plate (Figure 4). Then, the reinforcement cage is installed, and concrete is poured inside the tube. Finally, an outer ring vibrator is used to extract the tube from the soil, leaving the sacrificial plate in the soil.

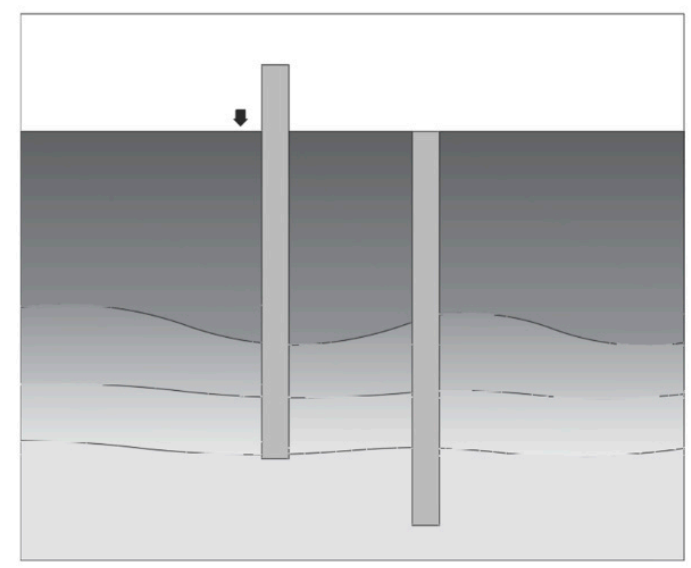

Figure 1. Precast prestressed concrete pile. 


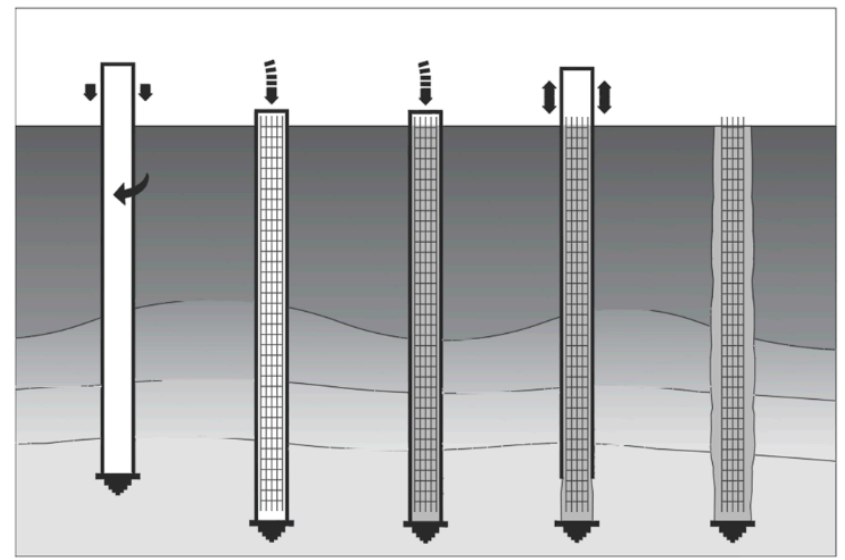

Figure 2. Fundex pile.

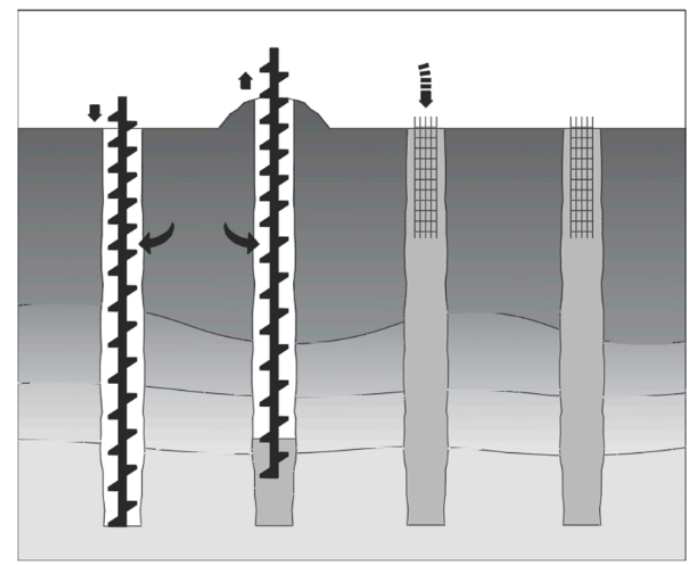

Figure 3. Continuous flight auger (CFA) pile.

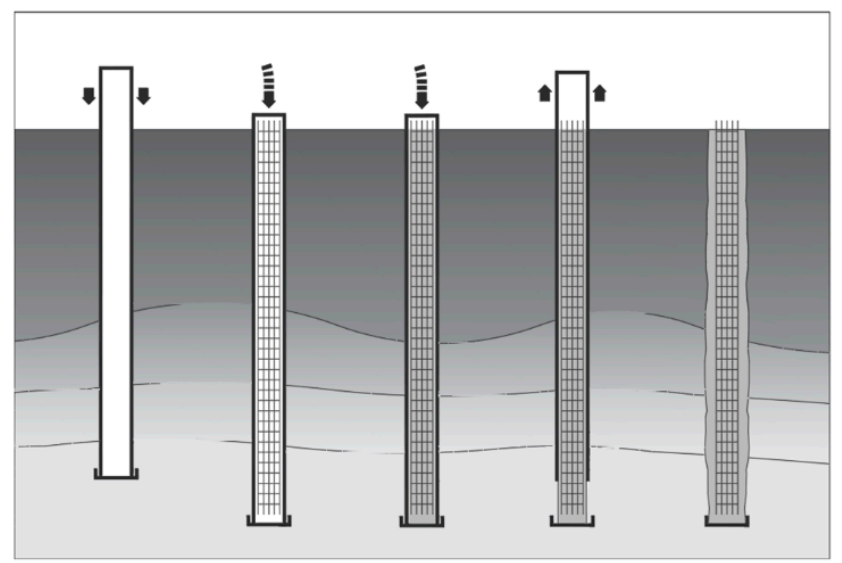

Figure 4. Vibro-pile.

Concretes for precast foundations tend to have higher strengths than cast in situ concrete because precast components are built in a factory where production conditions are more controlled and it is easier to obtain higher strengths. The nomenclature for concrete strength from the Eurocode consists of a capital C followed by two compressive strengths, one measured using concrete cylinder test specimens and the other using concrete cube specimens (e.g., C25/30) [15]. 


\subsection{Previous Literature}

Previous studies have reported that concrete and steel account for the highest greenhouse gas (GHG) emissions during the construction of deep concrete foundations (66-90\%), followed by equipment usage (12-19\%) and transportation (9-16\%) [14,16-19]. In addition, piles account for the majority of the environmental impact in a foundation compared to a concrete raft or pile caps. Therefore, it is desirable to reduce the environmental impact of foundation materials, particularly for piles.

The decisions made at the design stage are important because they affect the long-term impact of a foundation [20,21]. For instance, the use of precast concrete piles instead of CFA piles was shown to halve the environmental impact of a foundation, fully counteracting the extra emissions from prefabrication (higher concrete strength, more transport, and installation). The same study also reported that prefabrication may be more expensive than conventionally cast in situ methods, although this is closely related to the nature of each work (e.g., number of units, location). Conversely, Luo et al. [16] reported that precast concrete piles can create 5\% more GHG emissions than bored piles, with materials and transportation being points to be optimized. However, the emissions from the construction of precast concrete piles were closely related to the area, cost, and number of piles in a foundation [22].

The combination of variables in the design of a foundation also showed reductions in the GWP. For instance, the selection of the level of prefabrication, concrete strength, type, and calculation codes of a foundation reduced the GWP impact of the foundation by up to $50-60 \%[14,17]$. For this reason, this research also incorporated these variables and others derived from common practice with the intention that the resulting recommendations could be easily implemented in future foundation designs. Furthermore, the study also included some types of piles which are used in Northern Europe (PPC, Fundex, and vibro-piles) that have yet to be environmentally assessed. The economic cost was also included, since the implementation of a new solution in the construction sector depends significantly on its economic cost $[16,23,24]$. Additionally, a Pareto analysis was performed on building foundations to select the best alternatives in terms of the combination of costs and ecological burdens. Furthermore, the study focuses solely on the foundation and its environmental optimization [9,10], which is normally approached as part of a building [7]. In this respect, prior studies [14,16,17] optimized environmentally part of a foundation (i.e., a pile cap with piles, a footing, and only piles of a foundation); the present study aims to go one step further by considering the entire foundation of the building.

\subsection{Objectives}

The research is based on a real case and aims to optimize a conventional foundation for Northern Europe in terms of the environment by considering the economic cost and studying the variables of the prefabrication level (fully precast, semi-precast, and cast in situ), concrete strength of cast in situ piles (C20/25, C25/30, C30/37, C40/50), type of pile (precast prestressed concrete pile (PPC), continuous flight auger (CFA), Fundex, and vibro-pile), and the number of piles per ground beam ( 3 and 4 piles). The specific objectives are (i) to conduct a structural analysis to determine the dimensions of foundation alternatives; (ii) to calculate and analyze the environmental burden using LCA; (iii) to calculate and analyze the economic cost; (iv) to apply a Pareto analysis (the so-called Pareto front) to select the best solution(s), given a combination of the eco-burdens and costs; and (v) to assess the influence of the study variables on the environmental burden and the economic cost of a foundation and, in doing so, define specific design conclusions and recommendations.

\section{Materials and Methods}

The integrated methodology applied to determine the environmental influence of the study variables includes a selection of equivalent alternatives (Section 2.1), an explanation of a case study (Section 2.2), a definition of a functional unit (FU) (Section 2.3) as well as 
system boundaries (Section 2.4) and quantitative model (Section 2.5), an explanation of the foundation design (Sections 2.6 and 2.7) and LCA (Section 2.8), and a compilation of the data sources used (Section 2.9).

\subsection{Selection of Equivalent Alternatives}

The type of foundation and the study variables are common in usual Northern Europe practices. The abbreviations used to designate the study alternatives are shown in Table 1.

Table 1. Abbreviations used in the study.

\begin{tabular}{ccc}
\hline & Variables & Abbreviations \\
\hline 1 & Number of foundation & $1-28$ \\
\hline 2 & $\begin{array}{c}\text { Type of pile + diameter / side } \\
\text { of the pile (mm) }\end{array}$ & $\begin{array}{c}\text { Continuous flight auger pile (C), Vibro-pile (V), Fundex } \\
\text { pile (F), Precast prestressed concrete pile (P) }\end{array}$ \\
\hline 3 & Concrete strength & $\begin{array}{r}\text { Cast in situ: C20/25 (20), C25/30 (25), C30/37 (30), } \\
\text { C40/50 (40). Precast: 35/45 (35) }\end{array}$ \\
\hline 5 & Beam & $\begin{array}{c}\text { Cast in situ (I) (concrete is poured on site), Precast (P) } \\
\text { (concrete is poured in a specialized facility) }\end{array}$ \\
\hline 6 & Piles per beam & $(3)$ and (4) \\
\hline
\end{tabular}

Example: 1-C600-20/I3.650 is foundation number 1 and is composed of C600-20 piles and I3.650 beams. The C600-20 pile is a continuous flight auger pile $600 \mathrm{~mm}$ in diameter with a concrete strength of C20/25. I3.650 is a cast in situ beam supported by three piles with a width of $650 \mathrm{~mm}$.

\subsection{Case Study}

The reference project is a neutral energy housing project in Vianen (The Netherlands) (Figure 5) which is composed of 16 buildings with similar characteristics. The foundation of building 13 was selected for assessment (Figure 6). The foundation is composed of precast concrete piles and ground beams (Figure 7). The main characteristics of the foundation of the reference project are shown in Supplementary Material S1. The soil is composed of loose layers of sand that increase in resistance to levels of 8-10 $\mathrm{m}$ where the piles are embedded. The reference project has been adapted to better analyze the influence of the variables on the study results. For instance, the prefabricated concrete walls were turned into sand-lime brick and the partition walls into two $120 \mathrm{~mm}$ sand-lime bricks. Table 2 shows the building materials and permanent and variable loads considered in the study. Finally, wind load was not considered, given that it does not alter the results of the study.

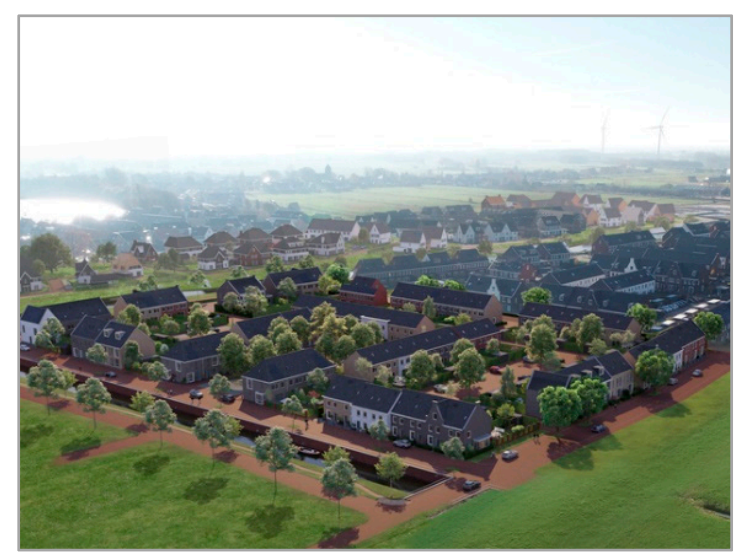

Figure 5. Aerial photo of the reference project [25]. 


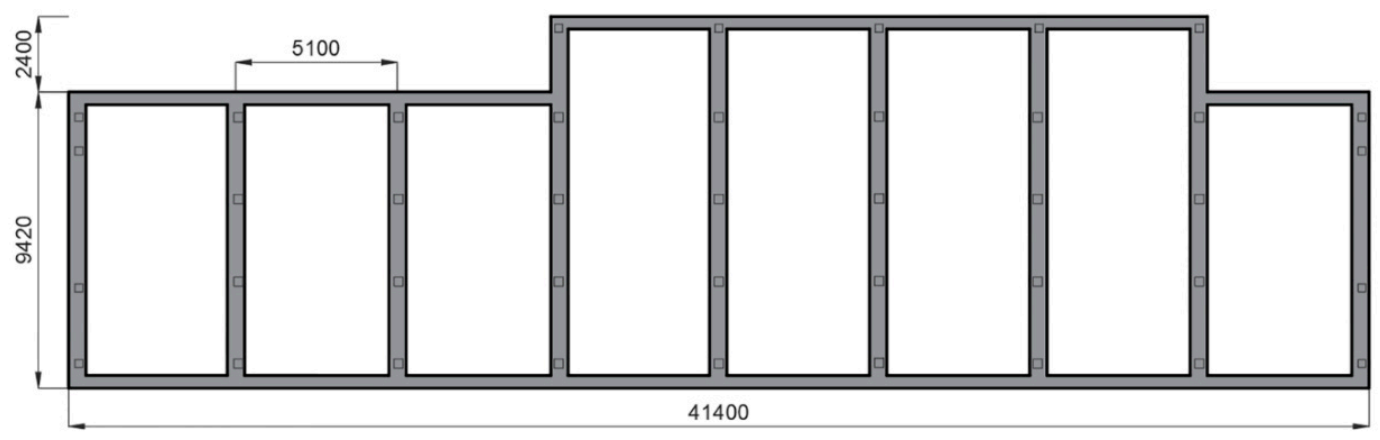

Figure 6. Foundation of building 13 of the reference project in Vianen.

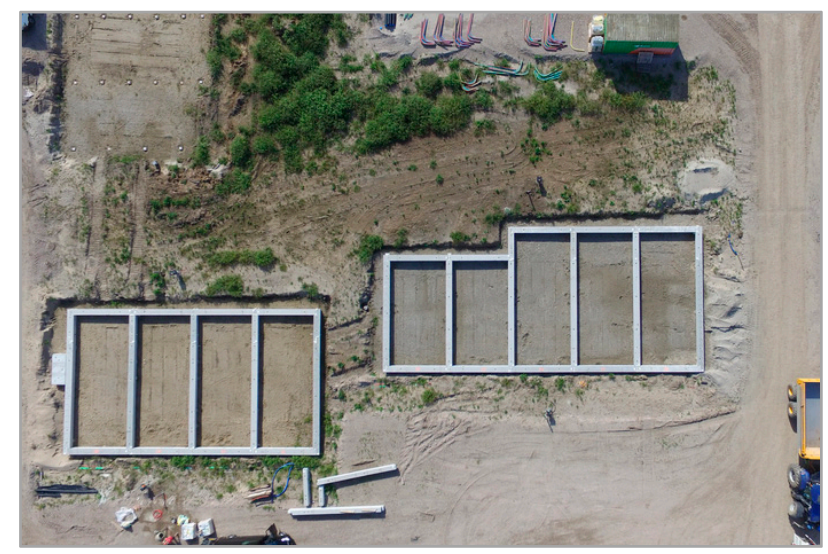

Figure 7. A foundation of the reference project [25].

Table 2. Building materials and permanent loads used in the study.

\begin{tabular}{ccc}
\hline Element & Construction System & Loads \\
\hline Ground floor & PS insulation floor & $3.6 / 2.55 \mathrm{kN} / \mathrm{m}^{2}$ \\
First and second floors & Concrete floor & $5.7 / 2.55 \mathrm{kN} / \mathrm{m}^{2}$ \\
Roof & Timber + tiles & $1.0 / 0.0 \mathrm{kN} / \mathrm{m}^{2}$ \\
Facades & Timber frame construction + masonry & $2.5 \mathrm{kN} / \mathrm{m}^{2}$ \\
Front facade & Sand-lime bricks + masonry & $4.3 \mathrm{kN} / \mathrm{m}^{2}$ \\
Building wall & $2 \times 120$ mm sand-lime bricks & $4.5 \mathrm{kN} / \mathrm{m}^{2}$ \\
Extension facade & construction & $4.3 \mathrm{kN} / \mathrm{m}^{2}$ \\
Roof extension & Sand-lime bricks + masonry & $5.5 / 0.0 \mathrm{kN} / \mathrm{m}^{2}$ \\
\hline
\end{tabular}

\subsection{Functional Unit}

The functional unit (FU) is a conventional foundation that consists of concrete ground beams and piles considering different levels of prefabrication, types of pile, concrete compressive strength, and number of piles per beam for a useful life of 50 years.

\subsection{System Boundaries}

Figure 8 shows the phases of the LCA and the elements considered in each of them. The phases comprise steps from the extraction of raw materials to the construction of the foundation on site. The various transports are included in the corresponding phases (e.g., the transport of raw material, products, waste, soil). The levelling of the ground prior to building the foundation was not considered because it is very specific to each work and does not alter the study comparison. Nevertheless, the excavation of each foundation has been considered because it is different depending on the alternative. The pumping of concrete and the transport of the machines to the site were excluded because a preliminary 
study showed that their environmental impact was low. The use phase was also excluded because well-designed foundations tend to not require maintenance. Similarly, the end of life was not considered because recycling or reusing foundations is not the norm, although there is great potential in this area [7]. The piles are usually left installed in the ground, although precast ground beams, which are a very recent foundation element, have not yet reached the end of their useful life. However, in cases where the precast ground beams were built in temporary buildings (10 and 15 years), which is not the usual case, at the end of their useful life, they were (i) reused in the same building, (ii) reused in another building. or (iii) dismantled and demolished. In cases (i) and (ii), the end of life was considered in the design stage of the beams.

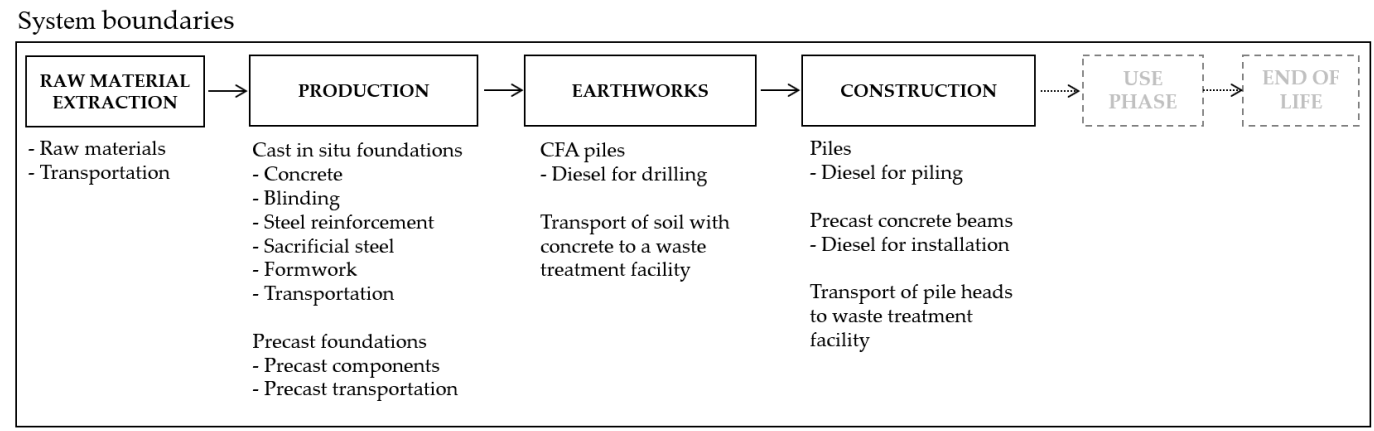

Figure 8. Life cycle diagram and system boundaries of the construction of the foundation alternatives.

\subsection{Quantitative Model for Environmental Impact Category Calculation}

Below the quantitative model used to calculate the eco-burdens for each category is shown [17].

$$
E=\sum_{i=1}^{n} \sum_{j=1}^{m} p_{i} Q_{i j}
$$

where $E$ is the single indicator score (i.e., Eco-costs 2017, ReCiPe 2016 Endpoint World (2010) H/A, GWP 100-year 2013 Intergovernmental Panel on Climate Change and cumulated energy demand) of the FU; $n$ is the total number of reference flows; $i$ is the reference flow (i.e., material, diesel, formwork, or transportation); $m$ is the total number of phases in the life cycle (i.e., 4$) ; j$ is the phase of the life cycle (i.e., raw material extraction, production, earthworks, or construction); $p_{i}$ is the combined factor for characterization, normalization, and weighting per unit of reference flow (e.g., factor per $\mathrm{kg}$ or $\mathrm{m}^{2}$ material); and $Q_{i j}$ is the quantity of reference flow in an FU phase.

\subsection{Structural Design of Ground Beams}

Loads were calculated according to NEN-EN 1990+A1+A1/C2:2019/NB:2019 [26] and NEN-EN 1991-1-1+C1+C11:2019/NB:2019 [27]. Reinforced concrete beams (cast in place and precast) were designed following NEN-EN 1992-1-1+C1:2011/NB:2016+A1:2020 [28]. Calculations of the beams were performed with Technosoft Balkroosters [29]. All the beams were designed for an XC3 environmental class (moderate humidity) according to Table 4.1 in [28], with concrete covers of $35 \mathrm{~mm}$ for cast in situ beams and $30 \mathrm{~mm}$ for precast beams complying with article 4.4.1 in [28]. In addition, cast-in-place beams were designed to be cast in a common removable timber formwork [30] so that all the alternatives could be compared without insulation. Additionally, they were designed to be built over a $50 \mathrm{~mm}$ concrete blinding [28]. The formwork was considered to be used 5 times. The concrete strength considered for cast in situ beams was C30/37, that for concrete blinding was $\mathrm{C} 12 / 15$, and that for precast beams was $C 40 / 50$, which is aligned with normal practices. However, different strengths of concrete for ground beams were not considered because a preliminary study showed that increasing the strength of concrete in 
beams minimally increases their resistance, because beams work mostly in bending rather than in compression. Ground beams were dimensioned following the usual Dutch practice. The height was set at $500 \mathrm{~mm}$ for all the ground beams (cast in situ and precast). For the cast-in-situ ground beams, a minimum width of $500 \mathrm{~mm}$ for transverse walls and $400 \mathrm{~mm}$ for longitudinal walls was established so that the width of the beams matched the width of the walls. However, for the precast floor beams, this was not necessary because the consoles, which are elements that protrude from both sides of the top of the beam, allow the beam to be adjusted to the width of the wall. It should be mentioned that consoles were not included in the material calculation of the study due to their low impact on the results. Finally, various PPC pile and wide beam foundation options were discarded from the study because they were oversized and unrealistic for reasons of economic cost, transportation, and installation.

\subsection{Geotechnical and Structural Design of Piles}

The bearing capacity of the piles was calculated following NEN 9997-1+C2:2017 [31]. All the piles were designed for an XC4 environmental class (cyclic wet and dry) according

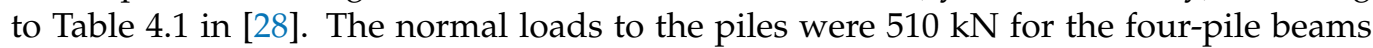
and $760 \mathrm{kN}$ for the three-pile beams. Concrete covers were designed to be $70 \mathrm{~mm}$ for CFA piles, $50 \mathrm{~mm}$ for Fundex piles, $40 \mathrm{~mm}$ for vibro-piles, and $30 \mathrm{~mm}$ for PPC piles, which is in line with article 4.4.1 in [28]. The concrete strengths considered for cast in situ piles were C20/25, C25/30, and C30/37, complying with NEN-EN 1536:2010+A1:2015 [32], and C35/45 for PPC piles according to product specifications. In most cases, the heads of the piles were not cut off. However, in Fundex piles, it has been considered that the pile head is cut off $(1 \mathrm{~m})$, which aligns with the usual practice. Afterwards, the heads of all types of piles were rebuilt with mortar, and a reinforcing bar was placed on top of each pile to connect them with the precast ground beams, which was not necessary for the cast-in-situ beams, since they were built directly on top of piles.

In terms of reinforcement, all the pile types were reinforced with the minimum amount of reinforcement, which is specified in Table 9.6 from [28], and an additional reinforcement was also calculated to resist the bending moment at the head of the pile $(38 \mathrm{kNm}$ in three-beam piles and $25.5 \mathrm{kNm}$ in four-beam piles). This bending moment arises from considering a $50 \mathrm{~mm}$ eccentricity in the structural calculations to cover possible unforeseen events, such as construction misalignments and horizontal forces. As a result, a larger pile diameter may be required to arm this bending moment. Furthermore, the minimum diameter considered for the longitudinal reinforcement was $12 \mathrm{~mm}$ in all piles [28], while for stirrups it was considered to be $6 \mathrm{~mm}$ in CFA piles, $8 \mathrm{~mm}$ in vibro-piles, and $5 \mathrm{~mm}$ in Fundex piles according to article 10.2.4 in [33]. The reinforcement for PPC piles was retrieved from product specifications. Finally, most of the piles were reinforced at all lengths, except CFA piles, which were reinforced only at the three superior meters [33], and an additional bar of $\varnothing 20 \mathrm{~mm}$ was arranged in the center of the CFA pile to compensate for the weakness of the superior layers of the soil (article 7.1.7 in [32]). Regarding cast in situ piles, the minimum cement content considered was $375 \mathrm{~kg} / \mathrm{m}^{3}$, complying with Annex D of [15], and a reduction in the pile diameter was applied to cover the uncertainty of building a pile directly on the ground following article 2.3.4.2 in [28].

The higher the concrete strength in the piles, the less steel reinforcement is required. It is worth mentioning that a higher concrete strength was not considered once the cast in situ piles reached the minimum steel reinforcement because it did not add information in the study. As previously mentioned, the environmental impact of the cubic meter of concrete is the same for the different concrete resistances in this study following the Dutch regulations. Therefore, rather than looking for the best option that may depend on each case (loads, soil, etc.), it is intended to detect the influence of the study variables on the environmental and economic results of the alternatives to consider them in future designs and codes of foundations. 


\subsection{Life Cycle Assessment}

The LCA method was applied to determine the environmental impact, as defined in international codes [34,35]. The software SimaPro version 9.2 [36] was used for the calculations. Since LCA is used here to determine whether "system A is better than System B", so-called "single score methods" are applied, as has been recommended by the Society of Environmental Toxicology and Chemistry [37] and the Joint Research Centre of the EU [38]. The calculations were performed for 4 indicator types: (i) carbon footprint, as a "single issue method"; (ii) ReCiPe, as a "damage-based method"; (iii) eco-costs, as a "monetized prevention-based method"; (iv) and embodied energy, as a "single issue method". In their sectors, these four indicators are the most applied methods in science. The eco-costs comply with [39]. Although monetization in LCA is not very common, the advantage of eco-costs is that they are so-called "external costs" (i.e., costs for our society that are not incorporated in the price of a product), so they have a direct meaning to architects, business managers, and governmental policy makers. Recently, there have been increasing applications of eco-costs in the building industry-e.g., for concrete construction [40] and beams [41]. Eco-costs are also applied in full cost accounting (FCA), which is also called true cost accounting (TCA). The basic philosophy behind TCA is that the external costs (=environmental burden) of a product should be added to the economic costs to enable a fair comparison in product benchmarking between a cheap but polluting product and a "clean" product. Another way to address the issue of "ecology versus economy" is to display the external costs and the economic costs in a two-dimensional graph and determine the Pareto front (being the best solution). Section 3.4 explains how such a Pareto analysis works in practice.

\subsection{Data Sources}

The economic and construction data were mainly provided by leading foundation and concrete companies in the Netherlands. Data from Vroom Funderingstechnieken [25] provided the quantities of diesel needed to install the various types of piles (CFA, Vibro, Prefab, and Fundex) and precast beams and the quantities of sacrificial steel for Fundex and Vibro piles. The specifications for the PPC piles were provided by a Dutch precast concrete company. Mebin B.V. [42] provided concrete dosages for cast in situ foundations. Most of the economic data were obtained from the EcoQuaestor database [43], except for the cast in situ concretes, which were provided by Mebin B.V. The installation and removal of machinery on site were not considered in either the environmental or economic costs due to their marginal influence on the study results.

Environmental data were retrieved from the Ecoinvent v.3.5 [44] and Idemat database [45]. The various piles used different types of steel. Nonetheless, the same steel was considered for all reinforcements (steel reinforcement with a working process) because not all steels were found in the consulted databases. In this regard, the importance of retrieving the data from the same databases should be remarked on to ensure a fair comparison. Please see Supplementary Material S2 for more information on the materials/processes and quantities introduced in SimaPro. The transport distances for materials and components were obtained from the literature and are summarized in Table 3. Note that these distances are for a trip by truck; however, in the study two trips by truck were considered (one to deliver the product and then another to return to the empty truck to the factory). 
Table 3. Transport distances used for calculation.

\begin{tabular}{|c|c|c|c|c|}
\hline \multirow[t]{2}{*}{ Item } & \multicolumn{2}{|c|}{ Transportation } & \multirow[t]{2}{*}{$\begin{array}{c}\text { Distances } \\
(\mathbf{k m})\end{array}$} & \multirow[t]{2}{*}{$\begin{array}{l}\text { Retrieved } \\
\text { from }\end{array}$} \\
\hline & From & To & & \\
\hline Cement & Place of production & $\begin{array}{c}\text { Concrete plant } \\
\text { Precast concrete plant }\end{array}$ & 75 & \multirow{5}{*}[14,17,46]{} \\
\hline Aggregates & Place of production & $\begin{array}{c}\text { Concrete plant } \\
\text { Precast concrete plant }\end{array}$ & 40 & \\
\hline $\begin{array}{l}\text { Steel } \\
\text { reinforce- } \\
\text { ment }\end{array}$ & Place of production & $\begin{array}{c}\text { Construction site } \\
\text { Precast concrete plant }\end{array}$ & 130 & \\
\hline Concrete & Place of production & Construction site & 30 & \\
\hline Soil & Construction site & Landfill sites & 30 & \\
\hline Waste & Construction site & $\begin{array}{l}\text { Waste management } \\
\text { facility }\end{array}$ & 30 & \\
\hline $\begin{array}{l}\text { Sawn } \\
\text { timber }\end{array}$ & Place of production & Construction site & 50 & [46] \\
\hline Additives & Place of production & $\begin{array}{c}\text { Concrete plant } \\
\text { Precast concrete plant }\end{array}$ & 100 & {$[14,17]$} \\
\hline $\begin{array}{c}\text { Precast } \\
\text { units }\end{array}$ & Precast concrete plant & Construction site & 150 & [47] \\
\hline
\end{tabular}

\section{Results and Discussion}

The results of the research are presented and discussed in the subsections below: structural results of the foundation alternatives (Section 3.1), environmental results of only piles (Section 3.2.1), environmental results of foundation alternatives (piles and beams) (Section 3.2.2), economic results of the foundation alternatives (Section 3.3), and the economic-environmental results of the foundation alternatives (Pareto front) (Section 3.4). Please find absolute values of the environmental and economic results in Supplementary Material S5.

\subsection{Structural Results}

Table 4 shows the study alternatives along with the main characteristics of the alternatives for later conducting the environmental and economic analysis. Please consult Supplementary Materials S3 and S4 for more information on the structural results.

Table 4. Main characteristics of the foundation alternatives.

\begin{tabular}{|c|c|c|c|c|c|}
\hline \multirow{2}{*}{$\begin{array}{c}\text { Foundation } \\
\text { Alternative Code }\end{array}$} & \multirow{2}{*}{ Number } & Piles & Concrete & Steel & Steel Reinforcement for Piles \\
\hline & & $\mathbf{u}$ & $\mathrm{m}^{3}$ & kg & \\
\hline 1-C600-20/I3.650 & 1 & 32 & 169 & 4900 & $7 \varnothing 16(3 \mathrm{~m})+\varnothing 25(10 \mathrm{~m})$ \\
\hline 2-V305-20/I3.500 & 2 & 32 & 70 & 11,540 & $8 \varnothing 20 *$ \\
\hline 3-V305-30/I3.500 & 3 & 32 & 70 & 9469 & $6 \varnothing 20 *$ \\
\hline $4-\mathrm{V} 305-40 / \mathrm{I} 3.500$ & 4 & 32 & 70 & 6568 & $5 \varnothing 16^{*}$ \\
\hline 5-V356-20/I3.500 & 5 & 32 & 81 & 6582 & $5 \varnothing 16^{*}$ \\
\hline 6-V356-25/I3.500 & 6 & 32 & 81 & 5132 & $5 \varnothing 12 *$ \\
\hline 7-F380-20/I3.500 & 7 & 32 & 83 & 7438 & $5 \varnothing 16 *$ \\
\hline 8-F460-20/I3.550 & 8 & 32 & 106 & 7651 & $7 \varnothing 12 *$ \\
\hline 9-P250-35/I4.500 & 9 & 41 & 66 & 2406 & $4 \varnothing 6.9$ * \\
\hline 10-P350-35/I3.500 & 10 & 32 & 92 & 3383 & $4 \varnothing 9.3^{*}$ \\
\hline $11-V 305-20 /$ P3.400 & 11 & 32 & 65 & 11,468 & $8 \varnothing 20 *$ \\
\hline 12-V305-30/P3.400 & 12 & 32 & 65 & 9397 & $6 \varnothing 20 *$ \\
\hline
\end{tabular}


Table 4. Cont.

\begin{tabular}{|c|c|c|c|c|c|}
\hline \multirow{2}{*}{$\begin{array}{c}\text { Foundation } \\
\text { Alternative Code }\end{array}$} & \multirow{2}{*}{ Number } & Piles & Concrete & Steel & Steel Reinforcement for Piles \\
\hline & & $\mathbf{u}$ & $\mathbf{m}^{3}$ & $\mathrm{~kg}$ & \\
\hline 13-V305-40/P3.400 & 13 & 32 & 65 & 6497 & $5 \varnothing 16^{*}$ \\
\hline 14-V356-20/P3.400 & 14 & 32 & 76 & 6510 & $5 \varnothing 16^{*}$ \\
\hline 15-V356-25/P3.400 & 15 & 32 & 76 & 5060 & $5 \varnothing 12 *$ \\
\hline 16-P350-35/P3.400 & 16 & 32 & 87 & 3311 & $4 \varnothing 9.3 *$ \\
\hline 17-C500-20/I4.550 & 17 & 32 & 151 & 4622 & $5 \varnothing 16(3 \mathrm{~m})+\varnothing 25(10 \mathrm{~m})$ \\
\hline 18-V273-30/I4.500 & 18 & 41 & 70 & 10,765 & $6 \varnothing 20 *$ \\
\hline 19-V273-40/I4.500 & 19 & 41 & 70 & 7048 & $5 \varnothing 16^{*}$ \\
\hline 20-V305-20/I4.500 & 20 & 41 & 78 & 7911 & $6 \varnothing 16^{*}$ \\
\hline 21-V305-30/I4.500 & 21 & 41 & 78 & 4727 & $4 \varnothing 12 *$ \\
\hline 22-F380-20/I4.500 & 22 & 41 & 95 & 6460 & $5 \varnothing 12 *$ \\
\hline 23-V273-30/P4.350 & 23 & 41 & 63 & 10,794 & $6 \varnothing 20 *$ \\
\hline 24-V273-40/P4.350 & 24 & 41 & 63 & 7077 & $5 \varnothing 16$ * \\
\hline 25-V305-20/P4.350 & 25 & 41 & 71 & 7940 & $6 \varnothing 16^{*}$ \\
\hline 26-V305-30/P4.350 & 26 & 41 & 71 & 4757 & $4 \varnothing 12 *$ \\
\hline 27-F380-20/P4.450 & 27 & 41 & 93 & 6554 & $5 \varnothing 12 *$ \\
\hline 28-P250-35/P4.300 & 28 & 41 & 64 & 2509 & $4 \varnothing 6.9 *$ \\
\hline
\end{tabular}

Terminology: foundation alternative number - type of pile (continuous flight auger (C), Vibro (V), Fundex (F), precast prestressed concrete (P) pile) + pile diameter/side (mm) - pile concrete strength (C20/25 (20), C25/30 (25), C30/37 (30), C35/45 (35), C40/50 (40))/Cast in situ (I) and precast (P) beams + (3) and (4) piles per beam + width of the beam (mm). * Reinforcement all the length of the pile.

\subsection{Environmental Results}

\subsubsection{Piles}

Figure 9 compares the GHG emissions of various piles from alternatives with cast in situ beams and three piles per beam. The piles from foundation alternatives with precast beams and four piles per beam are not shown, as they display a similar trend.

If we observe the environmental impact of each element in the construction of a pile (e.g., reinforcement, transport, etc.), concrete and steel play an important role in the environmental results of all piles, representing $65-95 \%$ of the impact. In addition, pile driving (i.e., drilling, driving, etc.) can represent up to $20 \%$ of the GWP and CED from pile construction, as is the case with Fundex piles, given that for this type of pile diesel is needed not only for piling but also for an external unit for pumping concrete. Additionally, the sacrificial steel in the Fundex pile type can represent up to 15\% of GWP, up to $25 \%$ of eco-costs, and $20 \%$ of ReCiPe and CED. Transportation in precast piles accounts for $15-20 \%$ of the environmental impact. However, the transportation of waste derived from installation in all piles has little impact on the environmental results.

If we compare the environmental impact between the piles, it can be observed that piles with the least amount of reinforcement obtained the best environmental results, namely precast piles with the smallest cross-sections (e.g., P250-35) and vibro-piles with the highest concrete strengths. On the other hand, the types of piles that obtained the worst environmental results were those with large amounts of concrete and/or steel. These included CFA piles (e.g., C600-20), vibro-piles with low concrete strengths and/or large amounts of reinforcement (e.g., V305-20), and Fundex piles with larger cross-sections (e.g., F460-20).

If we analyze the influence of the study variables on the environmental results of piles, we can see that prefabricated piles with the smallest cross-sections obtained the best environmental results (e.g., P250-35). Additionally, the increase in concrete strength in vibropiles led to reductions in GHG emissions, which is in line with a previous study [17]. Finally, four-pile ground beam piles obtained better results than three-pile ground beam piles because the latter have more steel reinforcement to compensate for higher buckling loads. 


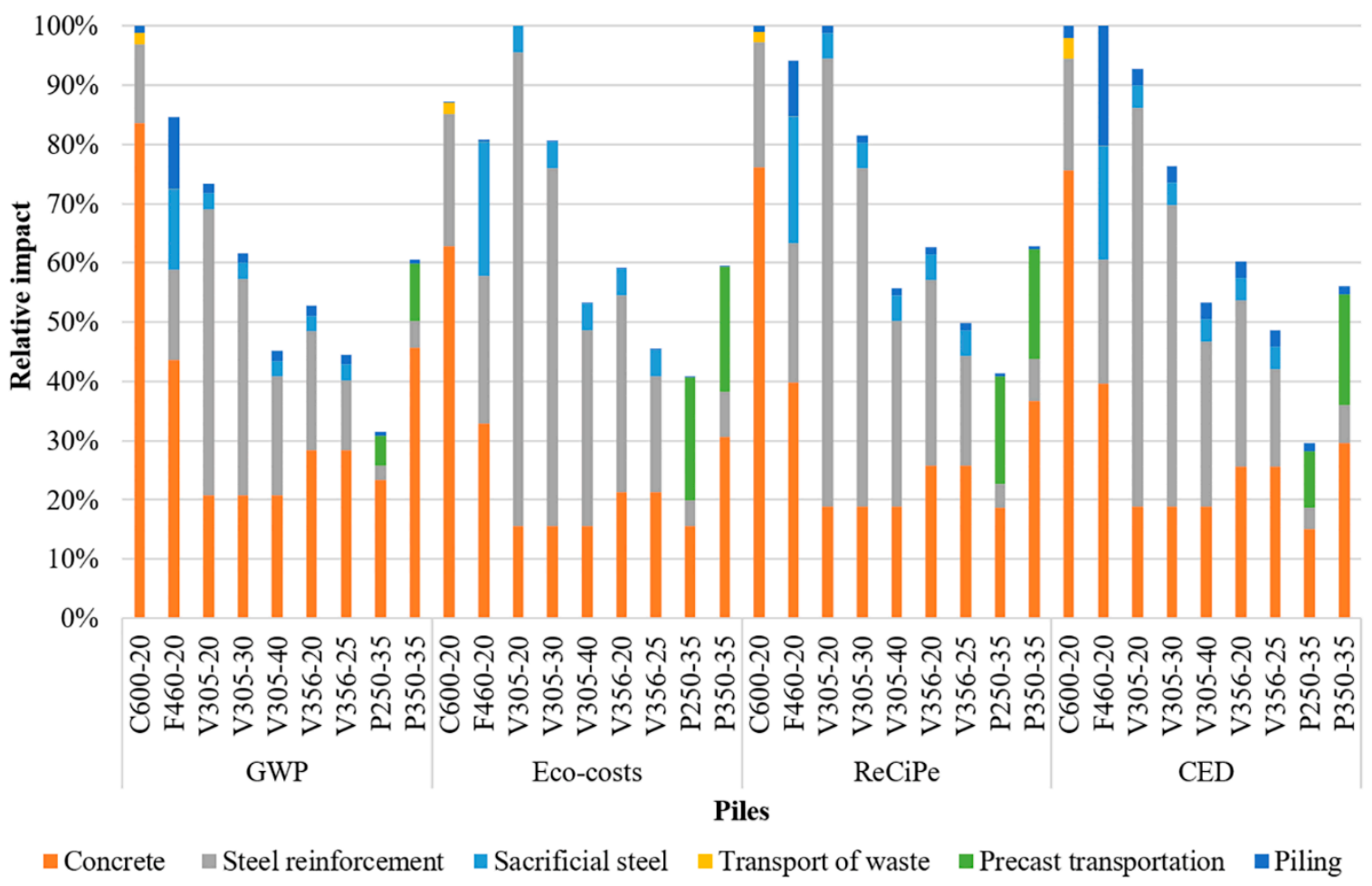

Figure 9. Relative impact of piles from beams with three piles considering the indicators of GWP, Eco-costs, ReCiPe, and CED. Terminology: type of pile (continuous flight auger (C), Vibro (V), Fundex (F), precast prestressed concrete (P) pile) + pile diameter/side (mm) - pile concrete strength (C20/25 (20), C25/30 (25), C30/37 (30), C35/45 (35), C40/50 (40)).

\subsubsection{Foundation Alternatives (Piles and Beams)}

Materials are the main contributor to environmental impact (85-95\%) in all indicators of the foundation alternatives, which is aligned with previous studies [14,17]. Figure 10 shows some of the relevant environmental results to allow for a discussion of the influence of study variables.

In terms of prefabrication, foundation alternatives with small cross-section precast piles (PPCs) obtained the best environmental results in the study (e.g., 9-28). However, the use of prefabricated beams instead of cast in situ beams increased the environmental impact of the foundation alternatives by up to $5 \%$ in terms of eco-costs, ReCiPe, and CED and 10\% in terms of GWP. This is because concrete in precast beams has a greater impact (more cement) than concrete in cast in situ beams. In this sense, concrete has a special effect on the GWP indicator, while steel is on the eco-cost indicator. Furthermore, precast ground beams require transportation to and installation at the building site, which far outweighs the impact of concrete blinding and the larger volumes of concrete in cast in situ beams. Most likely, as the beam becomes wider (precast or cast in situ), the amount of concrete and steel increases, and consequently, the environmental impact of the beam is higher. However, the prefabrication of ground beams might be interesting from a cradle-to-grave perspective [48], as they can have a prolonged service life (from reuse).

The design of the piles has an important effect on the environmental results of the hole foundation. Nevertheless, the type of pile itself is not a guarantee that the foundation alternative is sustainable, although the reduced amounts of concrete and particularly steel are sustainable. Nevertheless, it should be noted that some types of piles use fewer materials and resources than others to support the same load. The foundation alternatives that resulted in the lowest environmental impact compared to the worst environmental result were those with small cross-section PPC piles $(9,28)$, which obtained up to $55 \%$ lower environmental impacts, and vibro-piles with low amounts of reinforcement, which obtained up to $45 \%$ smaller impacts (e.g., $21 \rightarrow 4 \varnothing 12$ ). Surprisingly, these alternatives 
have the lowest amounts of steel reinforcement in the piles examined in this study. In contrast, the foundation alternatives that inflicted the greatest environmental impact were those with vibro-piles with large amounts of reinforcement (e.g., $11 \rightarrow 8$ Ø20), CFA piles (e.g., $1 \rightarrow$ diameter 600) with large amounts of concrete, and Fundex piles with moderately high amounts of concrete and steel, which includes the sacrificial steel (e.g., $8 \rightarrow$ diameter $460+7 \varnothing 12+160 \mathrm{~kg}$ tip).

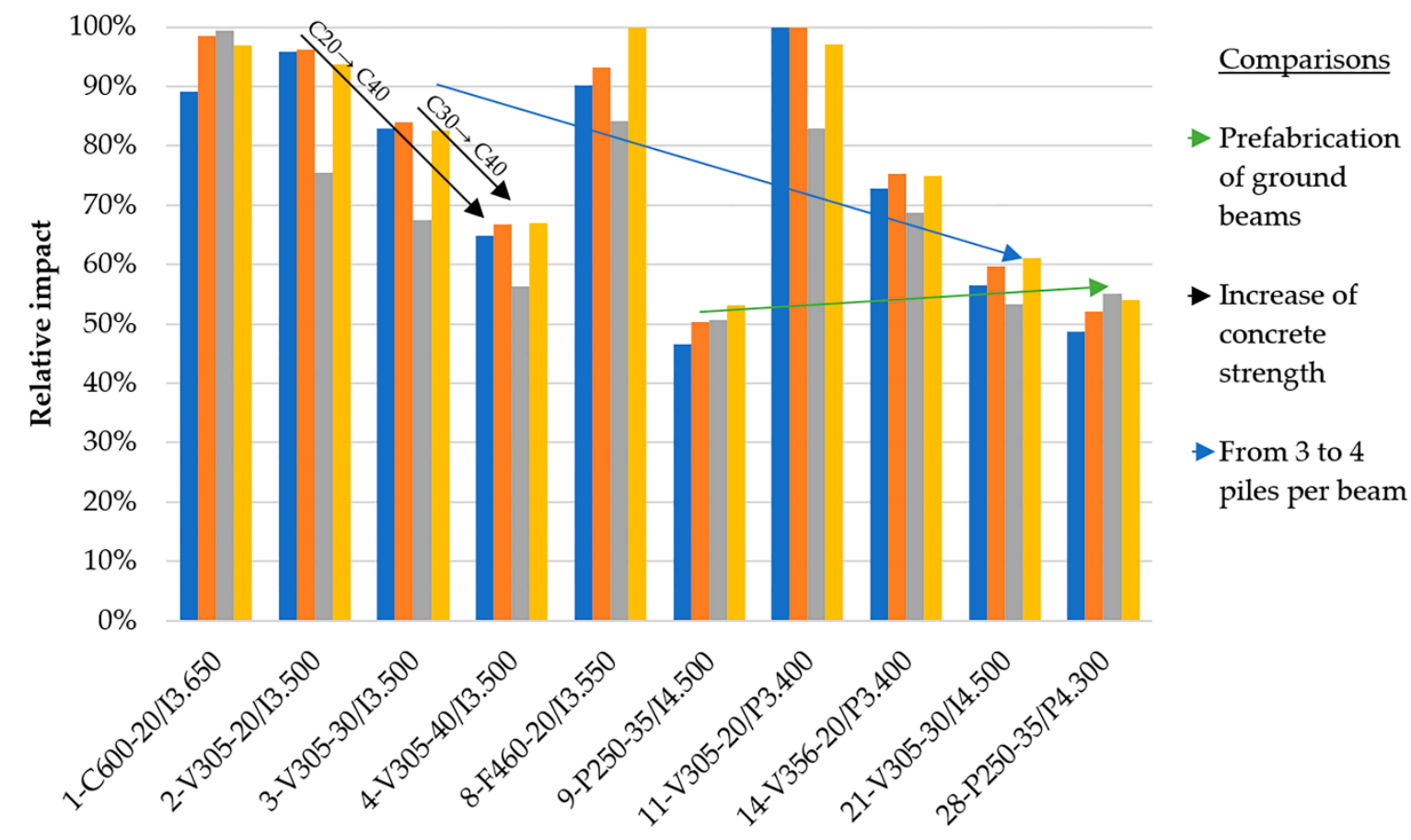

Foundation alternatives

$\square$ Ecocosts $\square$ ReCiPe $\square$ GWP $\square$ CED

Figure 10. Relative impact of the eco-costs, ReCiPe, GWP, and CED of relevant study foundation alternatives. Terminology: foundation alternative number - type of pile (continuous flight auger (C), Vibro (V), Fundex (F), precast prestressed concrete $(\mathrm{P})$ pile) + pile diameter/side (mm) - pile concrete strength (C20/25 (20), C25/30 (25), C30/37 (30), C35/45 (35), $\mathrm{C} 40 / 50(40)) /$ cast in situ (I) and precast (P) beams + (3) and (4) piles per beam + width of the beam (mm).

The increase in concrete strength in vibro-piles from $\mathrm{C} 20 / 25$ to $\mathrm{C} 40 / 50$ reduced the eco-cost, ReCiPe, and CED impacts by up to $30 \%$ and GWP by $25 \%$ (e.g., $2-4$ ). Similarly, the increase in concrete strength from C $30 / 37$ to C40/50 reduced the eco-costs and ReCiPe impacts by up to $25 \%$, and GWP and CED by up to $20 \%$ (e.g., 3-4). Surprisingly, vibro-piles that differed only in concrete strength had a similar impact from concrete but a different impact from steel (e.g., 3 and 4). This is explained because the concrete for cast in situ piles must have a minimal cement content of $375 \mathrm{~kg} / \mathrm{m}^{3}$ according to Dutch regulation [15], which assimilates the impact of concrete between cast-in-situ piles. However, the impact of steel between these piles is different because as the higher concrete strength is, the less steel reinforcement is required, since concrete contributes more to resisting the forces.

In terms of the number of piles in beams, four-pile foundations obtained $20-30 \%$ fewer impacts in eco-costs and ReCiPe, 15-20\% in GWP and 15-25\% in CED compared to those with three piles (e.g., 3-21). This is because less steel is required to compensate for the bending moments and shear forces in the beams and buckling forces in the piles.

Given the same beam, alternatives with vibro-piles that fit the beams better (i.e., larger piles) obtained $25-40 \%$ lower eco-costs and ReCiPe and up to 30\% lower GWPs and CEDs compared to smaller diameter piles (e.g., 11-14). This is because a larger diameter pile has a higher capacity since the axial forces are distributed over a larger surface and therefore the internal forces are smaller, reducing the required steel reinforcement. 


\subsection{Economic Results of Foundation Alternatives}

Piles accounted for $40-60 \%$ of the cost of foundation alternatives. Figure 11 shows some of the representative economic results of the study to allow for a discussion of the study variables. Foundation alternatives with piles with larger concrete pile crosssections incurred the highest economic costs (e.g., 1, 10, 16, 17), while foundations with low-reinforcement vibro-piles with precast beams (e.g., 15, 26) and cast in situ beams (e.g., 6 , 21 ) were the most economical options (up to $40 \%$ cheaper). The increase in the strength of concrete in vibro-piles considerably reduced the cost of the foundation by $7-10 \%$ from C20 to C30 and from C 30 to $\mathrm{C} 40$ and up to $15 \%$ from C20 to C40. This is because as the strength of the concrete increases, less steel reinforcement is required, although the cost of concrete is slightly higher. Moreover, foundations with four piles per beam were $7-12 \%$ more economical than foundations with three piles because the former have less steel reinforcement (e.g., 3-21). Alternatives with vibro-piles that fit the beams better (i.e., larger pile for the same beam) were up to $20 \%$ cheaper. Finally, foundations with the same piles and with precast or cast in situ beams obtained similar economic costs (approximately $5 \%$ up and down).
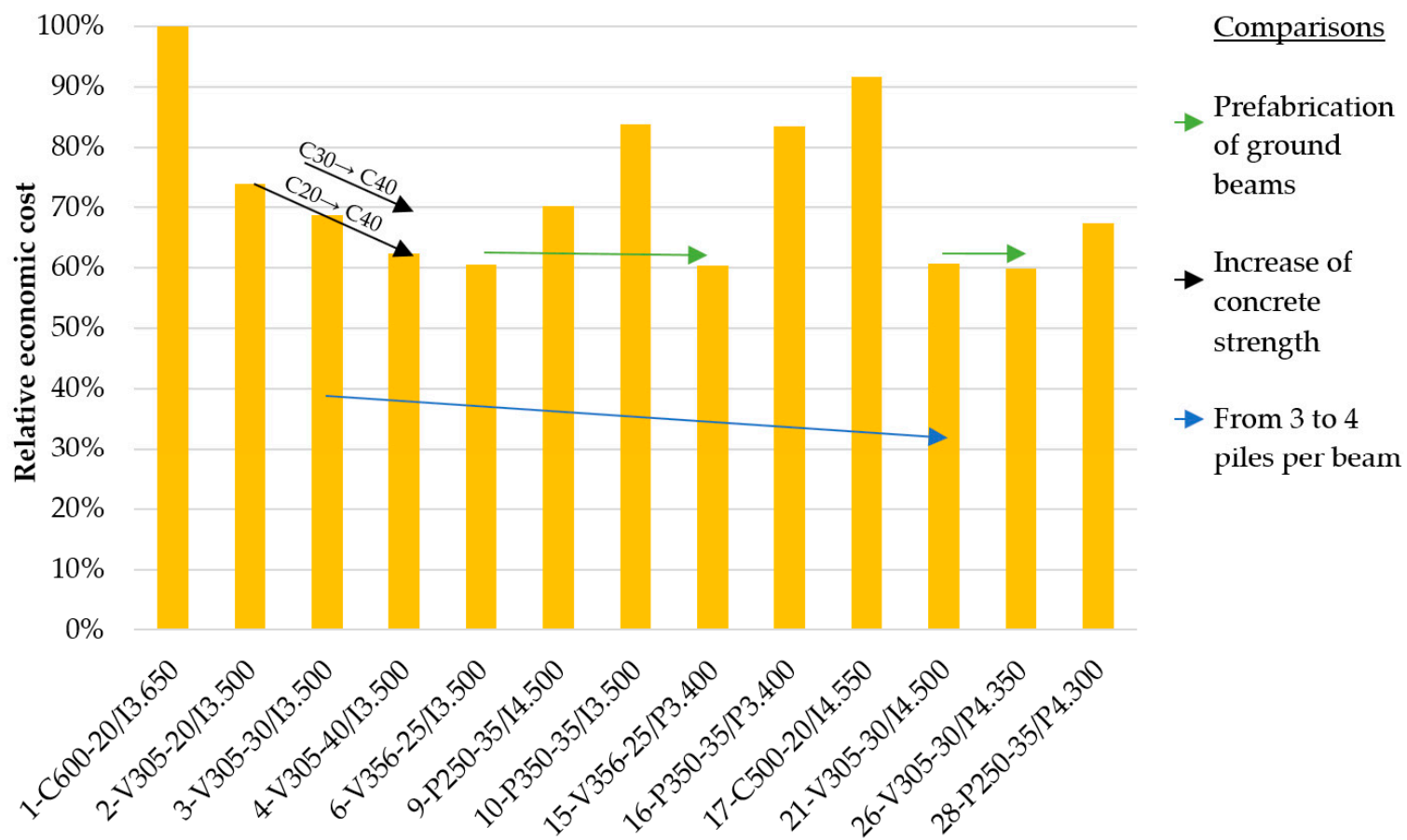

Foundation alternatives

Figure 11. Economic cost of relevant study foundation alternatives. Terminology: foundation alternative number - type of pile (continuous flight auger (C), Vibro (V), Fundex (F), precast prestressed concrete $(\mathrm{P})$ pile) + pile diameter $/$ side $(\mathrm{mm})$ - pile concrete strength (C20/25 (20), C25/30 (25), C30/37 (30), C35/45 (35), C40/50 (40))/cast in situ (I) and precast (P) beams $+(3)$ and $(4)$ piles per beam + width of the beam $(\mathrm{mm})$.

\subsection{Environmental-Economic Results of Foundation Alternatives (Pareto Front)}

The best choices on the basis of both economy and ecology are shown in Figures 12 and 13. In a one-dimensional system, there is one best choice, but in a two-dimensional system the best choices are given on a line: the so-called Pareto Front. A solution at the Pareto Front has no better alternative in the sense that there are no alternatives that score better on eco-costs and, at the same time, on costs. Such a solution is called Pareto Optimal, or Pareto Efficient [49]. There are many examples of this mathematical concept of multi-objective optimization (MOO), often related to the costs of energy conservation 
systems in the building industry [50], the refurbishment of buildings [51], and industrial processes [52]. The method is used to select the best solutions out of a cloud of alternatives and has the advantage that such a selection is still free of subjective choices.

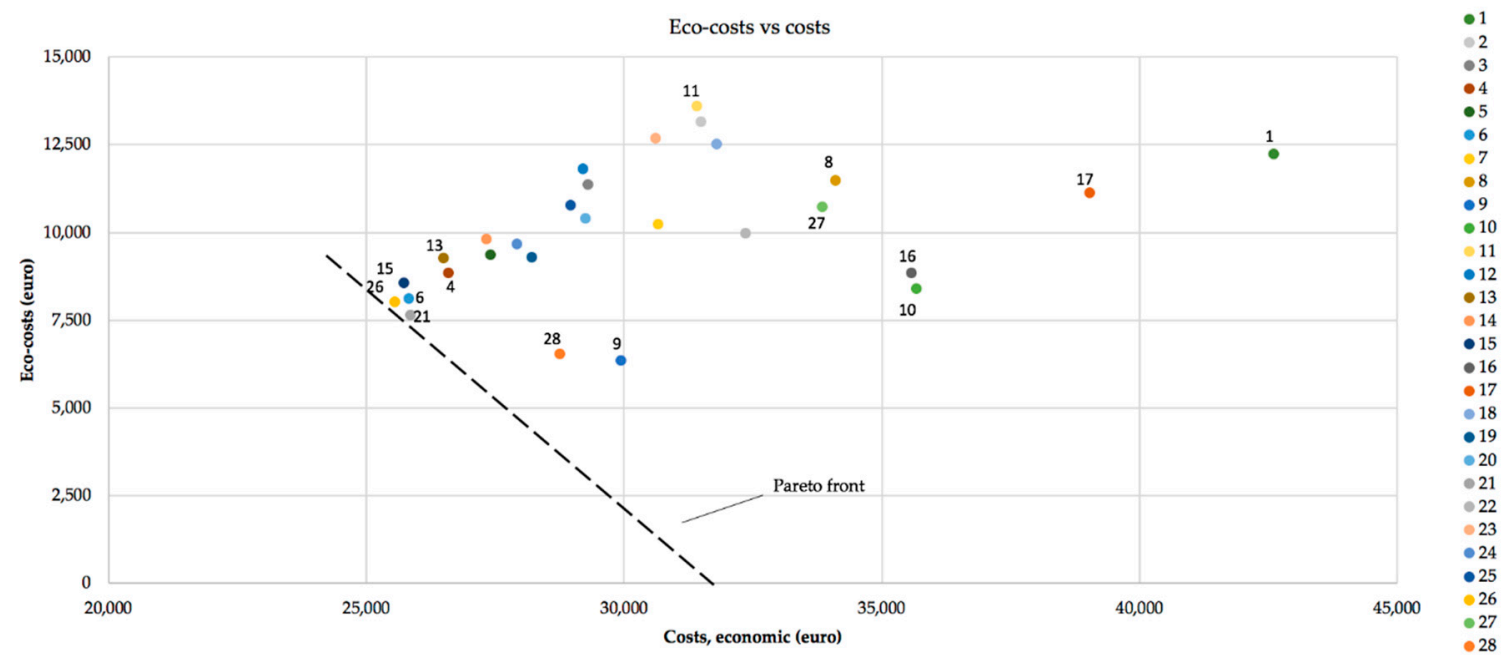

Figure 12. Pareto front of all foundation alternatives, eco-costs vs. costs. Note that the dotted line also depicts true costs $=$ eco-costs + costs $=$ constant (e.g., solutions 26 and 21 have the same true costs).

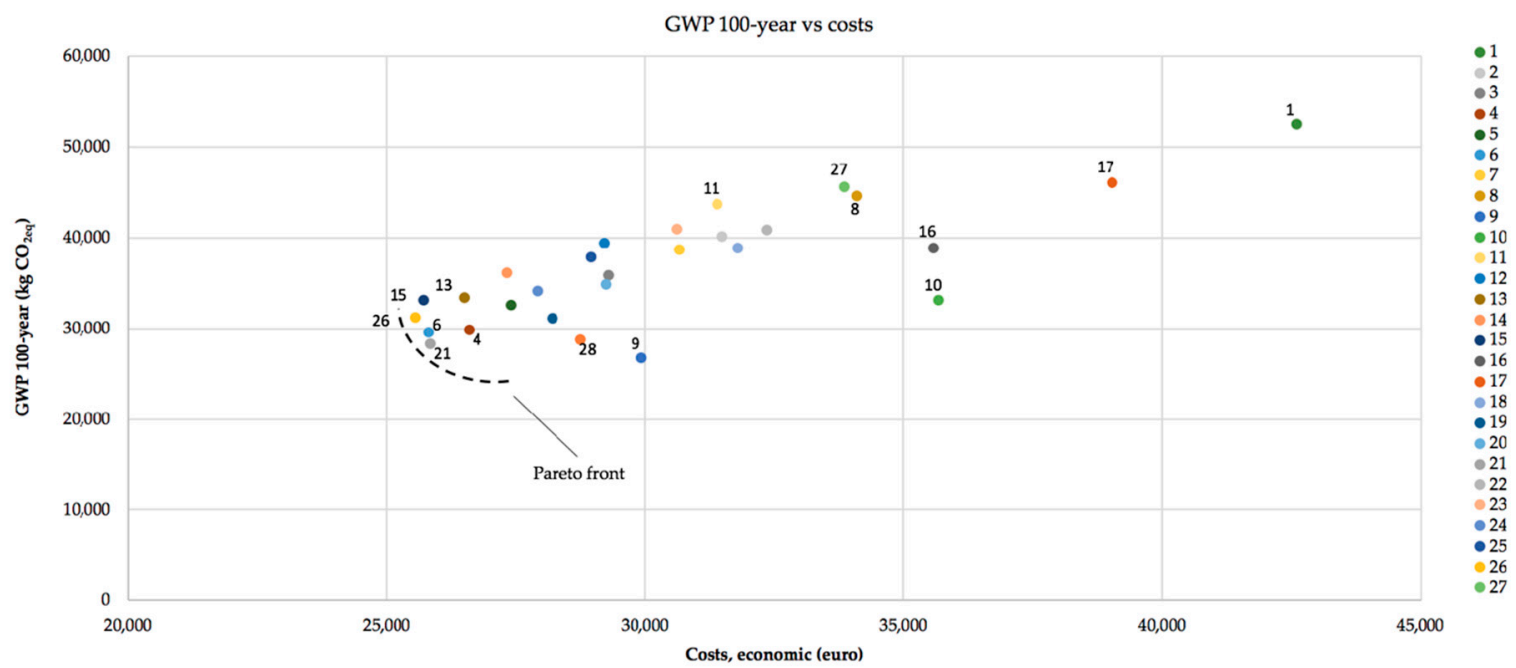

Figure 13. Pareto front of all foundation alternatives, 100-year GWP vs. costs.

A final choice of the best solution on the Pareto front, however, is a matter of a subjective choice-in this case, the relative importance of the eco-costs versus the costs (i.e., "how important is the ecology compared to the economy?"). A recent approach is to minimize the "true costs", where "true costs" = "eco-costs" + "costs" [53], and where "true costs" = "constant" is a straight line in Figure 12. In our case, it is a co-incidence that the Pareto front falls along this straight line. That means that, in this case, an additional subjective criterion must be applied to make a final choice. When the carbon footprint in Figure 13 is expressed in terms of money (e.g., the (future) price of carbon allowances, or the "eco-costs of carbon footprint"), the additional criterion of minimizing the true costs leads to a final choice.

The foundation alternatives that obtained the lowest results from this perspective were those composed of vibro-piles with a medium section $(305 \mathrm{~mm})$, low reinforcement (4Ø12), higher compressive concrete strengths (C30), four-pile cast in situ beams (21), and four-pile precast beams (26). It is worth mentioning that the same alternative with greater 
concrete strength (C40) was not considered because the amount of steel in the pile (21) is already the minimum established by regulations and therefore would have obtained similar environmental results. Second, the best-rated foundation alternatives were those with vibro-piles with a wide cross-section $(356 \mathrm{~mm})$, low reinforcement (5Ø12), the highest compressive concrete strength (C25), four-pile precast beams (15) and three-pile cast in situ beams (6). Surprisingly, these alternatives $(21,26,6,16)$ have the lowest amounts of steel reinforcement in cast in situ piles. Prefabricated piles with small cross-sections have even reduced amounts of reinforcement $(9,28)$. The alternatives with prefabricated piles of small cross-sections obtained the best environmental results (Section 3.2.2.), although from an environmental and economic perspective the aforementioned alternatives with vibropiles obtained better results because vibro-piles are cheaper (according to the database consulted). In contrast, the alternatives that obtained the worst results were the CFA piles with three and four piles per beam cast in situ $(1,17)$, as they required the highest amounts of concrete. Second, the worst-rated foundation alternatives were those with Fundex piles (8) and PPC piles $(10,16)$ with large pile cross-sections and highly reinforced vibro-piles (11). It should be mentioned that the larger the section of a pile was, the greater the width of the beam would be, thus increasing the amount of concrete.

\section{Conclusions}

An assessment has been presented, from an environmental and economic perspective, of the construction of a conventional building foundation composed of piles and ground beams according to the variables of level of prefabrication (fully precast, semiprecast, and cast in situ), the concrete strength of cast in situ piles (C20/25, C25/30, C30/37, C40/50), the type of pile (precast prestressed concrete (PPC), continuous flight auger (CFA), Fundex, and Vibro piles), and the number of piles per beam ( 3 and 4 piles). Some of the main conclusions of the study are summarized below.

- None of the study variables guarantees that a foundation is sustainable. However, a combination of selected variables can reduce the environmental impact by up to 55\% and the economic costs by up to $40 \%$ compared to the worst study alternatives. Materials accounted for $85-95 \%$ of the impact of the foundation; therefore, the combination of variables must guarantee a reduction in the impact of materials, particularly of steel on piles.

- From an environmental perspective, it is recommended to use PPC piles with small cross-sections because the environmental impact of the foundation is significantly reduced by up to $45-55 \%$ in all environmental indicators. It is also recommended to use vibro-piles with low amounts of reinforcement because the environmental impact can be reduced by up to $40-45 \%$. In contrast, it is not recommended to use CFA piles or highly reinforced vibro-piles in this type of foundation. In addition, the use of prefabricated beams instead of cast in situ beams increases the environmental impact of the foundation by up to $5 \%$ in terms of eco-costs, ReCiPe, and CED and up to $10 \%$ in GWP over 100 years. Moreover, increasing the compressive strength of concrete in vibro-piles is highly recommended because it reduces the environmental impact of the foundation. For instance, the increase in concrete strength from C20/25 to C40/50 reduces the eco-costs, ReCiPe, and CED by up to $30 \%$ and the GWP over 100 years by up to $25 \%$. Finally, the design of four piles per beam instead of three piles per beam can reduce the eco-costs and ReCiPe impact by 20-30\%, GWP over 100 years by $15-20 \%$, and CED by $15-25 \%$ due to the reduction in steel reinforcing amounts.

- From an economic perspective, it is preferable to select foundations with vibro-piles with high concrete strengths and with four-pile beams either cast in situ or prefabricated. Conversely, it is not recommended to select CPI piles or precast piles with large cross-sections. Additionally, increasing the strength of concrete from C20 to C30 and from C30 to C40 can reduce the cost of the foundation between $7 \%$ and $12 \%$ and from C20 to C40 by up to 15\%. Moreover, designing four piles instead of three can reduce the economic cost of the foundation by up to $12 \%$. 
- From an environmental and economic perspective (Pareto front), foundations should have low amounts of concrete and especially steel in the piles. Thus, it is recommended to use piles with reduced cross-sections, as their width also conditions the amount of materials in beams. However, reducing the pile cross-section may increase the amount of steel reinforcement in piles, and then the use of a higher concrete strength can moderate steel amounts. Vibro-piles with higher concrete strengths with cast in situ or prefabricated beams and four piles per beam are the most recommended alternatives from this perspective. Alternatives with CFA piles, Fundex piles, and PPC piles with large cross-sections and three piles per beam are the least recommended.

This paper has highlighted that changing certain common variables in the design of a foundation can significantly reduce the environmental and economic cost of the construction of a foundation. However, it must be considered that each type of pile has its optimal application that depends on many factors, such as the type of soil, loads, regulations, and tradition. Besides this, the economic cost of construction can be variable depending on the location and size of the work and the construction company, among other things. However, an attempt was made to minimize this uncertainty - on the one hand, by starting from a real case that was built, and on the other hand by using the databases and resources conventionally used in real practice. Future research could consider the study variables to optimize other constructive elements (slabs, etc.) and include other variables that lead to a significant reduction in environmental impact and economic cost. Likewise, it is interesting to consider other more sustainable materials (geopolymer concrete, biobased reinforcement, etc.) as well as other optimized designs [48]. This research aims to influence future buildings and codes to contribute to the improvement of environmental sustainability in the construction sector.

Supplementary Materials: The following are available online at https:/ /www.mdpi.com/2071-105 0/13/3/1496/s1.

Author Contributions: E.P.-G. was responsible for data curation, investigation, writing—original draft, and writing — review and editing; J.G.V. was responsible for data curation and writing-review and editing; S.P.G.M. was responsible for supervision and writing - review and editing. All authors have read and agreed to the published version of the manuscript.

Funding: This research received no external funding.

Institutional Review Board Statement: Not applicable.

Informed Consent Statement: Not applicable.

Data Availability Statement: Not applicable.

Acknowledgments: We would like to thank the following people for their advice, without whose help this work would never have been possible: Viola Friebel, Justin van der Eerden, Leo Dekker, Tim de Jonge, and Rawaz Kurda. We also want to thank Vroom Funderingstechnieken, Mebin B.V., and EcoQuaestor for the help provided.

Conflicts of Interest: The authors declare no conflict of interest.

\section{References}

1. Paris Agreement. Available online: https://ec.europa.eu/clima/policies/international/negotiations/paris_en (accessed on 17 January 2020).

2. IEA. GlobalABC Roadmap for Buildings and Construction 2020-2050-Analysis. Available online: https:/ /www.iea.org/reports/ globalabc-roadmap-for-buildings-and-construction-2020-2050 (accessed on 17 January 2020).

3. de Klijn-Chevalerias, M.; Javed, S. The Dutch approach for assessing and reducing environmental impacts of building materials. Build. Environ. 2017, 111, 147-159. [CrossRef]

4. Demertzi, M.; Silvestre, J.; Garrido, M.; Correia, J.R.; Durão, V.; Proença, M. Life cycle assessment of alternative building floor rehabilitation systems. Structures 2020, 26, 237-246. [CrossRef]

5. Ingrao, C.; Messineo, A.; Beltramo, R.; Yigitcanlar, T.; Ioppolo, G. How can life cycle thinking support sustainability of buildings? Investigating life cycle assessment applications for energy efficiency and environmental performance. J. Clean. Prod. 2018, $201,556-569$. 
6. Hoxha, E.; Habert, G.; Lasvaux, S.; Chevalier, J.; Le Roy, R. Influence of construction material uncertainties on residential building LCA reliability. J. Clean. Prod. 2017, 144, 33-47. [CrossRef]

7. Song, X.; Carlsson, C.; Kiilsgaard, R.; Bendz, D.; Kennedy, H. Life Cycle Assessment of Geotechnical Works in Building Construction: A Review and Recommendations. Sustainability 2020, 12, 8442. [CrossRef]

8. Emami, N.; Heinonen, J.; Marteinsson, B.; Säynäjoki, A.; Junnonen, J.-M.; Laine, J.; Junnila, S. A Life Cycle Assessment of Two Residential Buildings Using Two Different LCA Database-Software Combinations: Recognizing Uniformities and Inconsistencies. Buildings 2019, 9, 20. [CrossRef]

9. Ondova, M.; Estokova, A. Environmental impact assessment of building foundation in masonry family houses related to the total used building materials. Environ. Prog. Sustain. Energy 2016, 35, 1113-1120. [CrossRef]

10. Sandanayake, M.; Zhang, G.; Setunge, S. Environmental emissions at foundation construction stage of buildings-Two case studies. Build. Environ. 2016, 95, 189-198. [CrossRef]

11. Tomlinson, M.J.; Woodward, J. Pile Design and Construction Practice, 6th ed.; CRC Press, Taylor \& Francis Group: Boca Raton, FL, USA, 2014; ISBN 9781466592636.

12. Ay-Eldeen, M.K.; Negm, A.M. Global Warming Potential impact due to pile foundation construction using life cycle assessment. Electron. J. Geotech. Eng. 2015, 20, 4413-4421.

13. Bonamente, E.; Cotana, F. Carbon and energy footprints of prefabricated industrial buildings: A systematic life cycle assessment analysis. Energies 2015, 8, 12685-12701. [CrossRef]

14. Pujadas-Gispert, E.; Sanjuan-Delmás, D.; Josa, A. Environmental analysis of building shallow foundations: The influence of prefabrication, typology, and structural design codes. J. Clean. Prod. 2018, 186, 407-417. [CrossRef]

15. European Union. NEN-EN 206+NEN 8005:2017 Beton-Specificatie, Eigenschappen, Vervaardiging en Conformiteit + Nederlandse Invulling van NEN-EN 206; Nederlands Normalisatie Instituut: Delft, The Netherlands, 2017.

16. Luo, W.; Sandanayake, M.; Zhang, G. Direct and indirect carbon emissions in foundation construction-Two case studies of driven precast and cast-in-situ piles. J. Clean. Prod. 2019, 211, 1517-1526. [CrossRef]

17. Pujadas-Gispert, E.; Sanjuan-Delmás, D.; de la Fuente, A.; Moonen, S.P.G.; Josa, A. Environmental analysis of concrete deep foundations: Influence of prefabrication, concrete strength, and design codes. J. Clean. Prod. 2020, 244, 118751. [CrossRef]

18. Sandanayake, M.; Zhang, G.; Setunge, S.; Li, C.-Q.; Fang, J. Models and method for estimation and comparison of direct emissions in building construction in Australia and a case study. Energy Build. 2016, 126, 128-138. [CrossRef]

19. Zhang, X.; Wang, F. Assessment of embodied carbon emissions for building construction in China: Comparative case studies using alternative methods. Energy Build. 2016, 130, 330-340. [CrossRef]

20. Lee, M.; Basu, D. Environmental Impacts of Drilled Shafts and Driven Piles in Sand. In Proceedings of the IFCEE 2018, Orlando, FL, USA, 5-10 March 2018; American Society of Civil Engineers: Reston, VA, USA, 2018; pp. 643-652.

21. Lee, M.; Basu, D. Impacts of the Design Methods of Drilled Shafts in Sand on the Environment. In Proceedings of the Geo-Chicago 2016, Chicago, IL, USA, 14-18 August 2016; American Society of Civil Engineers: Reston, VA, USA, 2016 ; pp. 673-682.

22. Li, X.J.; Zheng, Y.D. Using LCA to research carbon footprint for precast concrete piles during the building construction stage: A China study. J. Clean. Prod. 2020, 245, 118754. [CrossRef]

23. Pujadas, E.; de Llorens, J.I.; Moonen, S.P.G. Prefabricated Foundations for 3D Modular Housing. In Proceedings of the 39th World Congress on Housing Science: Changing Needs, Adaptive Buildings, Smart Cities (IAHS), Milan, Italy, 17-20 September 2013; ISBN 978-84-16724-93-2.

24. Pujadas Gispert, E. Prefabricated Foundations for Housing Applied to Room Modules. Ph.D. Thesis, Universitat Politècnica de Catalunya, Barcelona, Spain, 2016.

25. Vroom Funderingstechnieken. Available online: https://www.vroom.nl/ (accessed on 17 January 2020).

26. European Union. NEN-EN 1990+A1+A1/C2:2019/NB:2019 Nationale Bijlage bij NEN-EN 1990+A1:2006+A1:2006/C2:2019 Eurocode: Grondslagen van het Constructief Ontwerp; Nederlands Normalisatie Instituut: Delft, The Netherlands, 2019.

27. European Union. NEN-EN 1991-1-1+C1+C11:2019/NB:2019 Nationale Bijlage bij NEN-EN 1991-1-1+C1+C11: Eurocode 1: Belastingen op Constructies-Deel 1-1: Algemene Belastingen-Volumieke Gewichten, Eigen Gewicht en Opgelegde Belastingen voor Gebouwen; Nederlands Normalisatie Instituut: Delft, The Netherlands, 2019.

28. European Union. NEN-EN 1992-1-1+C1:2011/NB:2016+A1:2020 Nationale Bijlage bij NEN-EN 1992-1-1+C2 Eurocode 2: Ontwerp en Berekening van Betonconstructies_Deel 1-1: Algemene Regels en Regels voor Gebouwen; Nederlands Normalisatie Instituut: Delft, The Netherlands, 2020.

29. Technosoft. Balkroosters. Available online: https://www.technosoft.nl/rekensoftware/producten/balkroosters (accessed on 17 January 2020).

30. Bouwbestel. Available online: https:/ / www.bouwbestel.nl/ (accessed on 17 January 2020).

31. European Union. NEN 9997-1+C2:2017 Geotechnisch Ontwerp van Constructies-Deel 1: Algemene Regels; Nederlands Normalisatie Instituut: Delft, The Netherlands, 2017.

32. European Union. NEN-EN 1536:2010+A1:2015 en Uitvoering van Bijzonder Geotechnisch werk—Boorpalen; Nederlands Normalisatie Instituut: Delft, The Netherlands, 2015.

33. NVN 6724:2001 Voorschriften Beton-In de Grond Gevormde Funderingselementen van Beton of Mortel; Nederlands Normalisatie Instituut: Delft, The Netherlands, 2001. 
34. ISO. Environmental Management_Life Cycle Assessment_Principles and Framework; ISO 14040:2006; International Organization for Standardization: Geneve, Switzerland, 2006; Volume 1997.

35. ISO. Environmental Management-Life Cycle Assessment-Requirements and Guidelines. ISO 14044:2006; International Organization for Standardization: Geneve, Switzerland, 2006.

36. PRé SimaPro 9.2. Available online: https://pre-sustainability.com/ (accessed on 17 January 2020).

37. Kägi, T.; Dinkel, F.; Frischknecht, R.; Humbert, S.; Lindberg, J.; De Mester, S.; Ponsioen, T.; Sala, S.; Schenker, U.W. Session "Midpoint, endpoint or single score for decision-making?"-SETAC Europe 25th Annual Meeting, May 5th, 2015. Int. J. Life Cycle Assess. 2016, 21, 129-132. [CrossRef]

38. Sala, S.; Cerutti, A.K.; Pant, R. Development of a Weighting Approach for the Environmental Footprint; Publications Office of the European Union: Luxembourg, 2018; ISBN 97892796804127.

39. ISO 14008:2019-Monetary Valuation of Environmental Impacts and Related Environmental Aspects. Available online: https: / / www.iso.org/standard/43243.html (accessed on 17 January 2020).

40. Hrabova, K.; Teply, B.; Vymazal, T. Sustainability assessment of concrete mixes. In Proceedings of the IOP Conference Series: Earth and Environmental Science, Ostrava, Czech Republic, 25-27 November 2019; IOP Publishing: Bristol, UK, 2020.

41. Zula, T.; Kravanja, S. Optimization of the sustainability profit generated by the production of beams. In Proceedings of the 1st International Conference on Technologies \& Business Models for Circular Economy, Portorož, Slovenia, 5-7 September 2018.

42. Mebin, B.V. Available online: https:/ / www.mebin.nl/nl (accessed on 17 January 2020).

43. EcoQuaestor. Available online: https://www.ecoquaestor.nl/de-aanpak/ecokosten/ (accessed on 17 January 2020).

44. Ecoinvent. Available online: https:/ / www.ecoinvent.org/ (accessed on 17 January 2020).

45. Idemat. Available online: https:/ / www.ecocostsvalue.com/EVR/model/theory/5-data.html (accessed on 17 January 2020).

46. Kellenberger, D.; Althaus, H.-J. Relevance of simplifications in LCA of building components. Build. Environ. 2009, 44, 818-825. [CrossRef]

47. Concrete Centre. The Concrete Centre Sustainability Performance Report; 1st Report; Concrete Centre: Surrey, UK, 2009.

48. van Loon, R.R.L.; Pujadas-Gispert, E.; Moonen, S.P.G.; Blok, R. Environmental optimization of precast concrete beams using fibre reinforced polymers. Sustainability 2019, 11, 2174. [CrossRef]

49. Pareto Efficiency Definition. Available online: https://www.investopedia.com/terms/p/pareto-efficiency.asp (accessed on 17 January 2021).

50. Caldas, L.G.; Norford, L.K. Genetic Algorithms for Optimization of Building Envelopes and the Design and Control of HVAC Systems. J. Sol. Energy Eng. 2003, 125, 343-351. [CrossRef]

51. Ostermeyer, Y.; Wallbaum, H.; Reuter, F. Multidimensional Pareto optimization as an approach for site-specific building refurbishment solutions applicable for life cycle sustainability assessment. Int. J. Life Cycle Assess. 2013, 18, 1762-1779. [CrossRef]

52. Bernier, E.; Maréchal, F.; Samson, R. Life cycle optimization of energy-intensive processes using eco-costs. Int. J. Life Cycle Assess. 2013, 18, 1747-1761. [CrossRef]

53. True Cost Economics Definition. Available online: https://www.investopedia.com/terms/t/truecosteconomics.asp (accessed on 17 January 2021). 